\title{
PENGARUH PEMBERIAN MAKANAN TAMBAHAN PEMULIHAN (PMT-P) TERHADAP STATUS GIZI KURANG PADA BALITA DI WILAYAH KERJA PUSKESMAS SEGALA MIDER BANDAR LAMPUNG
}

\author{
Setiawati ${ }^{1}$, Lidya Aryanti $^{2}$, Santy Anggraini ${ }^{3}$ \\ ${ }^{1}$ Dosen Program Studi Keperawatan Universitas Malahayati \\ Email: setiawati1477@yahoo.com.au \\ 2 Dosen Program Studi Keperawatan Universitas Malahayati \\ Email: lidyaaryanti@yahoo.com \\ ${ }^{3}$ Mahasiswa Program Studi Keperawatan Universitas Malahayati \\ Email: santyanggraini611@gmail.com
}

\section{ABSTRACT: EFFECT OF SUPPLEMENTARY RECOVERY FEEDING (PMT-P) ON MALNUTRITION STATUS OF TODDLERS IN THE WORKING AREA OF SEGALA MIDER HEALTH CENTER BANDAR LAMPUNG}

Backrgound: Nutritional problems of toddlers need attention. The World Health Organization (WHO) reports that there are 99 million toddlers suffering from malnutrition. Data in Indonesia in 2018 states that the percentage of malnutrition among children aged 0-59 months is 3.9\%, while the percentage of malnutrition is $13.8 \%$. Data in Lampung Province states that the percentage of malnutrition and malnutrition among children aged $0-59$ months is $3.1 \%$ for malnutrition and 12.8 for malnutrition. Data from the Bandar Lampung Health Service in 2019, it was found that there were targets for malnourished toddlers, namely as many as 1,277 toddlers and the largest was at the Segala Mider Health Center, as much 76 toddlers.

Purpose: To determine the effect of supplementary recovery feeding (PMT-P) on under-nutrition status in children under five.

Method: This type of research is quantitative, with a one group pretest posttest design. The population was all malnourished toddlers who received PMT-P in the work area of the Puskesmas All Mider Bandar Lampung, with a total sample of 30 children. The sampling technique used purposive sampling. The analysis in this study used a dependent t-test. Dependent t-test / paired sample t-test..

Results: The results of the univariate analysis showed that the mean z-score before the supplementary feeding recovery (PMT-P) program was $-2,391 \pm 0,214$ and after the PMT-P program increased to $-1,431 \pm 0.476$. The results of the difference between the two mean z-score increases before and after the PMT-P program were implemented of 0,959 and obtained $p$-value $=0,000$. The conclusions from the results of the study showed there is an effect of supplementary recovery feeding (PMT-P) on malnutrition status in children under five. So it is hoped that health workers can be more routine in providing health education to people who have toddlers, especially about toddler nutrition and provide leaflets on fulfilling toddler nutrition.

Keywords : PMT-P, malnutrition status, toddlers 
INTISARI: PENGARUH PEMBERIAN MAKANAN TAMBAHAN PEMULIHAN (PMT-P) TERHADAP STATUS GIZI KURANG PADA BALITA DI WILAYAH KERJA PUSKESMAS SEGALA MIDER BANDAR LAMPUNG

Latar Belakang: Masalah gizi balita parlu mendapat perhatian. World Health Organization (WHO) melaporkan bahwa terdapat 99 juta Balita menderita gizi kurang. Data di Indonesia tahun 2018, menyebutkan persentase gizi buruk pada balita usia 0-59 bulan adalah sebesar 3,9\%, sedangkan persentase gizi kurang adalah 13,8\%. Data di Provinsi Lampung, menyebutkan persentase gizi buruk dan gizi kurang pada balita usia 0-59 bulan yaitu sebesar 3,1\% untuk gizi buruk, dan 12,8 untuk gizi kurang. Data Dinas Kesehatan Bandar Lampung tahun 2019, diperoleh bahwa terdapat sasaran balita gizi kurang yaitu sebanyak 1.277 balita dan terbanyak yaitu di Puskesmas Segala Mider yaitu 76 balita.

Tujuan: Diketahui pengaruh pemberian makanan tambahan pemulihan (PMT-P) terhadap status gizi kurang pada balita.

Metode: Jenis penelitian ini adalah kuantitatif, dengan rancangan one group pretest posttest. Populasi yaitu seluruh balita gizi kurang yang mendapatkan PMT-P di wilayah kerja Puskesmas Segala Mider Bandar Lampung, dengan jumlah sampel sebanyak 28 balita. Teknik sampling menggunakan purposive sampling. Analisis pada penelitian ini menggunakan uji-t dependen. Uji t dependen/ paired sample t-test.

Hasil: Hasil analisis univariat bahwa rerata nilai z-skore sebelum dilakukan program pemberian makanan tambahan pemulihan (PMT-P) yaitu -2,391 $\pm 0,214$ dan setelah dilakukan program PMT-P meningkat menjadi $-1,431 \pm 0,476$. Hasil nilai beda dua mean peningkatan z-skore sebelum dan sesudah dilaksanakan program PMT-P sebesar 0,959 dan diperoleh $p$-value $=0,000$. Kesimpulan dari hasil penelitian menunjukkan terdapat pengaruh pemberian makanan tambahan pemulihan (PMT-P) terhadap status gizi kurang pada balita. Sehingga diharapkan bagi tenaga kesehatan dapat lebih rutin lagi dalam memberikan pendidikan kesehatan kepada masyarakat yang memiliki balita khususnya tentang asupan gizi balita serta memberikan leaflet tentang pemenuhan gizi balita.

Kata Kunci :PMT-P, status gizi kurang, balita

\section{PENDAHULUAN}

Kesehatan anak bertujuan untuk mempersiapkan generasi yang sehat, cerdas, dan berkualitas serta untuk menurunkan angka kematian anak. Untuk itu diperlukan upaya pemeliharaan kesehatan anak yang dilakukan sejak janin masih dalam kandungan, dilahirkan, setelah dilahirkan, dan sampai berusia delapan belas tahun. Masalah kesehatan pada anak yang tersering adalah masalah gizi (Kementerian Kesehatan Republik Indonesia, 2018).

Masalah gizi pada anak perlu mendapatkan perhatian. Masalah gizi kurang masih tersebar luas di negara- negara berkembang termasuk di Indonesia, dimana dampak masalah ditimbulkan akibat asupan gizi yang kurang diantaranya Kurang Energi Protein (KEP), Kekurangan Vitamin A (KVA), Gangguan Akibat Kekurangan Yodium (GAKY), dan Anemia. Selain itu, dampak masalah gizi akan berpengaruh terhadap perkembangan otak dan perilaku, kemampuan bekerja dan produktivitas serta daya tahan terhadap penyakit infeksi (Sulistyoningsih, 2011).

World Health Organization (WHO) melaporkan bahwa terdapat 99 juta anak di bawah usia 5 tahun (Balita) menderita gizi kurang di dunia 
diantaranya 67\% terdapat di Asia dan $29 \%$ di Afrika serta terdapat kematian 6,34 juta anak usia dibawah 5 tahun atau hampir 17 ribu kematian setiap harinya akibat penyakit infeksi dan status gizi (WHO; dalam Darwis, 2017).

Gizi kurang dan gizi buruk masih merupakan masalah di Indonesia. Data Riset Kesehatan Dasar (Riskesdas) tahun 2018 yang diselenggarakan oleh Kementerian Kesehatan menyatakan bahwa persentase gizi buruk pada balita usia 0-59 bulan yeng terjadi di wilayah Indonesia adalah sebesar 3,9\%, sedangkan persentase gizi kurang adalah 13,8\%. Hal tersebut tidak berbeda jauh dengan hasil Pemantauan Status Gizi (PSG) yang diselenggarakan oleh Kementerian Kesehatan tahun 2017, dimana persentase gizi buruk pada balita usia 0-59 bulan sebesar 3,8\% dan persentase gizi kurang sebesar 14,0\% (Kementerian Kesehatan Republik Indonesia, 2018).

Berdasarkan dara Riset Kesehatan Dasar (Riskesdas) tahun 2018 di Provinsi Lampung, persentase gizi buruk dan gizi kurang pada balita usia 0-59 bulan yaitu sebesar 3,1\% untuk gizi buruk, dan 12,8 untuk gizi kurang. Sedangkan untuk Kota Bandar Lampung, persentase gizi buruk dan gizi kurang pada balita usia 0-59 bulan masih lebih tinggi dibandingkan ratarata Kabupaten di Provinsi Lampung yaitu sebesar 3,02\% untuk gizi buruk, dan 13,07 untuk gizi kurang, jauh lebih tinggi dibandingkan dengan Kota Metro yang hanya sebesar $1,7 \%$ untuk gizi buruk, dan 8,61untuk gizi kurang (Kementerian Kesehatan Republik Indonesia, 2018).

Data Dinas Kesehatan Bandar Lampung tahun 2019, diperoleh bahwa terdapat sasaran balita gizi kurang yaitu sebanyak 1.277 balita. Berdasarkan data dari 29 Puskesmas di Bandar Lampung, jumlah sasaran balita gizi kurang terbanyak yaitu di
Puskesmas Segala Mider yaitu 76 balita, kemudian Puskesmas Satelit yaitu 74 balita, selanjutnya Puskesmas Sumur Batu yaitu 73 balita, kemudian Puskesmas Kemiling yaitu 70 balita dan Puskesmas Panjang yaitu 66 balita (Dinas Kesehatan Bandar Lampung, 2019).

Penelitian yang dilakukan oleh Zahra (2018), tentang perbedaan berat badan sebelum dan sesudah pemberian makanan tambahan pemulihan (PMT-P) bagi balita gizi kurang di Wilayah Kerja Puskesmas Pekalongan, Lampung Timur, diperoleh bahwa hasil analisis univariat diperoleh rerata berat badan sebelum dan sesudah Pemberian Makanan Tambahan Pemulihan (PMT-P) yaitu sebesar 8,67 $\mathrm{kg}$ dan $9,36 \mathrm{~kg}$. Analisis bivariat diperoleh adanya perbedaan berat badan sebelum dan sesudah Pemberian Makanan Tambahan Pemulihan ( $p$-value $=0,000)$.

Puskesmas Segala Mider merupakan puskesmas dengan sasaran balita gizi kurang tertinggi di Bandar Lampung. Berdasarkan data di Puskesmas Segala Mider Bandar Lampung pada tahun 2019, terdapat balita yang mengalami gizi kurang berjumlah 76 balita. Jumlah ini meningkat dari tahun sebelumnya yaitu 30 balita gizi kurang. Kegiatan PMT-P akan dilakukan kepada balita berstatus gizi kurang tersebut.

Berdasarkan latar belakang diatas, peneliti tertarik melakukan penelitian untuk mengetahui "Pengaruh Pemberian Makanan Tambahan Pemulihan (PMT-P) terhadap status gizi kurang dan buruk pada balita di wilayah kerja Puskesmas Segala Mider Bandar Lampung Tahun 2020".

\section{METODOLOGI PENELITIAN}

Jenis penelitian yang digunakan dalam penelitian ini adalah jenis penelitian kuantitatif. Penelitian ini 
menggunakan

praeksperiment dengan rancangan One Group Pretest Postest. Populasi dalam penelitian ini adalah seluruh balita gizi kurang yang mendapatkan PMT-Pdi wilayah kerja Puskesmas Segala Mider Bandar Lampung, pada priode April s.d Juli 2020 sebanyak 28 balita. Penelitian dilaksanakan di wilayah kerja Puskesmas Segalamider Bandar Lampung. Waktu dilaksanakan penelitian ini pada pada bulan April
2020 sampai dengan Juli 2020. Variabel Bebas (Independent) pemberian PMT-P, Variabel Terikat (Dependent) Status gizi balita. Alat pengumpul data pada penelitian ini adalah dengan menggunakan lembar observasi. Uji ini dilakukan untuk mengidentifikasi hubungan variable bebas dan variable terikat. Uji statistik menggunakan uji $t$-dependen dengan tingkat kemaknaan 95\% (a $0,05)$.

\section{HASIL PENELITIAN DAN PEMBAHASAN}

\section{A. Hasil Penelitian \\ 1. Analisis Univariat \\ a. Karakteristik Responden}

Tabel 1.

Distribusi Frekuensi Karakteristik Orang Tua

\begin{tabular}{lcc}
\hline \multicolumn{1}{c}{ Karakteristik } & Jumlah & Persentase \\
\hline Usia: & 8 & \\
$-\quad<20$ Tahun & 14 & 28.6 \\
- 20-35 Tahun & 6 & 50.0 \\
- >35 Tahun & & 21.4 \\
\hline Pendidikan: & 4 & \\
- Tamat SD & 14 & 14.3 \\
- Tamat SMP & 10 & 50.0 \\
- Tamat SMA & & 35.7 \\
\hline Pekerjaan: & 7 & \\
- Buruh & 16 & 25.0 \\
- IRT & 5 & 57.1 \\
$-\quad$ Wiraswasta & 28 & 17.9 \\
\hline Total & & 100.0 \\
\hline
\end{tabular}

Berdasarkan tabel 1. diketahui bahwa sebagian besar responden dengan rentang usia 20-35 tahun yaitu sebanyak 14 responden (50\%), merupakan tamatan SMP sebanyak 14 responden $(50 \%)$, tidak bekerja atau sebagai ibu rumah tangga yaitu sebanyak 16 responden (57.1\%).

\section{b. Status Gizi Balita Sebelum Pemberian PMT-P}

Tabel 2.

Rerata Nilai Z-Skore Balita Sebelum Diberi PMT-P

\begin{tabular}{ccccc}
\hline Variabel & Mean & SD & Min-Mak & $\mathrm{N}$ \\
\hline Z-Skore sebelum & $-2,391$ & 0,214 & $\begin{array}{c}-2,92 \text { s.d }- \\
\text { pemberian PMT-P }\end{array}$ & 28 \\
\end{tabular}


Hasil analisis didapatkan rerata nilai z-skore adalah sebelum dilakukan program pemberian makanan tambahan pemulihan (PMT-P) yaitu -
2,391 $\pm 0,214$ (status gizi kurang) dengan nilai terendah adalah $-2,92$ dan tertinggi $-2,09$.

\section{c. Status Gizi Balita Sesudah Pemberian PMT-P}

Tabel 3.

Rerata Nilai Z-Skore Balita Setelah Diberi PMT-P

\begin{tabular}{ccccc}
\hline Variabel & Mean & SD & Min-Mak & $\mathrm{N}$ \\
\hline Z-Skore sesudah & $-1,431$ & 0,476 & $-2,25 \mathrm{s.d}-$ & 28 \\
pemberian PMT-P & & & 0,36 & \\
\hline
\end{tabular}

Hasil analisis didapatkan rerata nilai z-skore setelah dilakukan pemberian makana tambahan pemulihan (PMT-P) yaitu $-1,431 \pm 0,476$ (status gizi normal) dengan nilai terendah adalah $-2,25$ dan tertinggi $-0,36$.

2. Analisis Bivariat

Tabel 4.

Pengaruh Pemberian Makanan Tambahan Pemulihan (PMT-P) Terhadap Status Gizi Kurang Pada Balita

\begin{tabular}{lcccccc}
\hline \multicolumn{1}{l}{ Variabel } & Beda 2 Mean & Mean & Std. Dev & Std. Error & $\rho$ Value & $N$ \\
\hline $\begin{array}{l}\text { Z-Skore } \\
\text { sebelum } \\
\text { pemberian }\end{array}$ & & $-2,391$ & & & & \\
PMT-P & & & & & & \\
& $-0,959$ & & 0,525 & 0,099 & 0,000 & 28 \\
$\begin{array}{l}\text { Z-Skore } \\
\text { sesudah }\end{array}$ & & $-1,431$ & & & & \\
pemberian & & & & & & \\
PMT-P & & & & & & \\
\hline
\end{tabular}

Hasil penelitian didapatkan rerata zskore sebelum dan sesudah dilaksanakan program PMT-P mengalami peningkatan sebesar 0,959 . Hasil uji statistik didapatkan $p$ value $=0,000$. Hal ini dapat disimpulkan bahwa terdapat

\section{PEMBAHASAN}

\section{Univariat}

\section{a. Status Gizi Balita Sebelum Pemberian PMT-P}

Berdasarkan hasil penelitian diperoleh bahwa rerata nilai z-skore

$\begin{array}{llr}\text { sebelum dilakukan } & \begin{array}{r}\text { program } \\ \text { pemberian }\end{array} \\ \text { makananahan }\end{array}$ pengaruh pemberian makanan tambahan pemulihan (PMT-P) terhadap status gizi kurang pada balita di wilayah kerja Puskesmas Segalamider Bandar Lampung Tahun 2020. pemulihan (PMT-P) yaitu $-2,391 \pm$ 0,214 (status gizi kurang) dengan nilai terendah adalah -2,92 dan tertinggi $-2,09$.

Hasil penelitian ini sesuai dengan teori yang dikemukakan oleh Tanto (2014), bahwa gizi kurang merupakan suatu spektrum dari kelainan yang disebut malnutrisi energi protein 
(MEP) derajat sedang, yang merupakan salah satu dari empat masalah gizi di indonesia yang prevalensi tertingginya terdapat pada anak dibawah lima tahun (balita). Gizi kurang belum menunjukan gejala klinis yang khas, hanya dijumpai gangguan pertumbuhan dan tampak kurus. Menurut Kementerian Kesehatan Republik Indonesia (2017), balita gizi kurang merupakan balita dengan status gizi kurang berdasarkan indikator $\mathrm{BB} / \mathrm{U}$ dengan nilai zscore : 2 SD sampai dengan <-3 SD. Menurut Supariasa (2017), faktor yang mempengaruhi terjadinya masalah gizi kurang antara lain adalah konsumsi makanan. Pengukuran konsumsi makanan sangat penting untuk mengetahui kenyataan apa yang dimakan oleh masyarakat dan hal ini dapat berguna untuk mengukur status gizi dan menemukan faktor diet yang dapat menyebabkan malnutrisi. Selain itu, faktor yang mempengaruhi terjadinya masalah gizi kurang adalah faktor sosial ekonomi dan juga faktor pendidikan yang berkaitan dengan pengetahuan tentang pemenuhan gizi balita dan penyediaan makanan keluarga.

Hasil penelitian ini sejalan dengan penelitian yang dilakukan oleh Fitrianti (2012), tentang pengaruh pemberian makanan tambahan pemulihan (PMT-P) terhadap status gizi balita gizi buruk di Dinas Kesehatan Kota Semarang, diperoleh bahwa sebelum pemberian PMT-P diperoleh $100 \%$ balita memiliki gizi kurang.

Menurut peneliti, rerata nilai zskore sebelum dilakukan program pemberian makanan tambahan pemulihan (PMT-P) merupakan keadaan awal yang menggambarkan status gizi balita dimana z-skore tersebut berada dalam ketegori status gizi kurang. Kejadian status gizi kurang pada tersebut dapat disebabkan oleh bermacam faktor, antara lain adalah karakteristik orang tua balita antara lain pekerjaan orang tua balita yang bersangkutan. Berdasarkan penelitian, sebagian besar responden adalah ibu rumah tangga (IRT) atau tidak bekerja $(57,1 \%)$, sehingga hanya mengandalkan pekerjaan suami untuk memenuhi kebutuhan nutrisi seharihari. Berdasarkan hasil observasi dan wawancara kepada responden, sebagian besar memang memiliki penghasilan keluarga yang pas-pasan untuk memenuhi kebutuhan makan sehari-hari, hal tersebut sangat berpengaruh terhadap pemenuhan nutrisi pada Balitanya. Kemudian, status gizi kurang responden berkaitan dengan pendidikan (50\%), dimana berdasarkan hasil penelitian juga didapatkan sebagian besar ibu hamil berpendidikan rendah. Orang tua yang berpendidikan rendah cenderung memiliki keterbatasan dalam hal memperoleh pengetahuan tentang bagaimana seharusnya ia melakukan pemenuhan kebutuhan nutrisi dan menyusun menu sehat seimbang pada Balitanya, sehingga Balita tersebut sangat berisiko untuk mengalami gizi kurang.

\section{b. Status Gizi Balita Setelah Pemberian PMT-P}

Berdasarkan hasil penelitian diperoleh bahwa rerata nilai z-skore setelah dilakukan program pemberian makanan tambahan pemulihan (PMTP) yaitu $-1,431 \pm 0,476$ (status gizi normal) dengan nilai terendah adalah $-2,25$ dan tertinggi $-0,36$.

Hasil penelitian ini sesuai dengan teori yang dikemukakan oleh Kementerian Kesehatan Republik Indonesia (2017), bahwa makanan tambahan merupakan makanan bergizi sebagai tambahan selain makanan utama bagi kelompok sasaran guna memenuhi kebutuhan gizi. Makanan tambahan pemulihan bagi balita adalah makanan bergizi yang diperuntukkan bagi balita usia 659 bulan sebagai makanan tambahan 
untuk pemulihan gizi. Makanan tambahan untuk balita merujuk pada seluruh makanan tambahan yang diberikan ketika posyandu (PMT penyuluhan); makanan tambahan khusus diberikan untukbalita kurus yang diberikan selama 90 hari makan (PMT pemulihan).PMT Pemulihan hanya sebagai tambahan terhadap makanan yang dikonsumsi oleh balita sasaran sehari hari, bukan sebagai pengganti makanan utama. PMT Pemulihan dimaksudkan untuk memenuhi kebutuhan gizi balita sasaran sekaligus sebagai proses pembelajaran dan sarana komunikasi antar ibu dari balita sasaran.

Hasil penelitian ini sejalan dengan penelitian yang dilakukan oleh Rini (2017) tentang pengaruh pemberian makanan tambahan pemulihan (PMTP) terhadap perubahan status gizi balita gizi buruk di Rumah Gizi Kota Semarang tahun 2017 diketahui bahwa terdapat perubahan skorz balita sebelum dan sesudah PMT-P. Perubahan rerata indeks antropometri BB/U adalah 0,62 SD dengan standar deviasi 0,03.

Menurut peneliti, rerata nilai zskore setelah dilakukan program pemberian makanan tambahan pemulihan (PMT-P) merupakan gambaran pengukuran terhadap indikator status gizi Balita setelah dilaksanakannya program pemberian makanan tambahan pemulihan (PMTP) yang dilakukan selama kurun waktu 3 bulan (90 hari). Balita telah diberikan perlakuan melalui program pemberian biskuit makanan tambahan pemulihan (PMT-P) yang telah terintegrasi dengan pelayanan Posyandu di Puskesmas. Setiap balita diberikan makanan tambahan berupa biskuit dimana tiap bungkus makanan tambahan berisi 4 keping biskuit (40 gram), balita dengan usia 12-59 bulan diberikan 12 keping (3 bungkus) per hari. Selain itu, orang tua balita juga disarankan untuk memberikan makanan utama dengan kandungan gizi yang seimbang. Berdasarkan hasil penelitian diperoleh adanya peningkatan rerata z-skore setelah dilaksanakannya program tersebut, dimana hal tersebut berarti ada perubahan status gizi balita akibat pelaksanaan program PMT-P yang telah diberikan. Namun berdasarkan hasil penelitian juga terdapat ada 4 balita yang walaupun secara pengukuran terdapat peningkatan zskore tetapi masih dalam kategori gizi kurang. Hal ini dapat disebabkan karena PMT-P juga hanya merupakan tambahan terhadap makanan utama, jika pada makanan utama tidak terjadi perubahan dalam hal nilai gizinya, maka peningkatan status gizi akibat pemberian PMT tidak akan maksimal.

\section{Bivariat}

Berdasarkan hasil penelitian diperoleh bahwa terdapat pengaruh pemberian makanan tambahan pemulihan (PMT-P) terhadap status gizi kurang pada balita di wilayah kerja Puskesmas Segala Mider Bandar Lampung Tahun $2020 \quad(p$ value $=0,000$ ).

Hasil penelitian ini sesuai dengan teori yang dikemukakan oleh Marimbi, (2012), bahwa ada beberapa hal yang sering merupakan penyebab terjadinya gizi kurang yang terjadi baik secara langsung maupun tidak langsung. Sebagai penyebab langsung gangguan gizi, khususnya gangguan gizi pada bayi dan anak usia dibawah lima tahun (balita) adalah tidak sesuainya jumlah gizi yang mereka peroleh dari makanan dengan kebutuhan tubuh mereka. Untuk itu diperlukan pemberian makanan tambahan untuk memenuhi kebutuhan gizinya. Menurut Kementerian Kesehatan Republik Indonesia(2018), bahwa makanan tambahan untuk balita antara lain meliputi seluruh makanan tambahan yang diberikan ketika posyandu (PMT penyuluhan) serta makanan 
tambahan khusus diberikan untuk balita kurus yang diberikan selama 90 hari makan (PMT pemulihan). Pemberian suplementasi gizi merupakan suatu upaya yang dapat dilakukan dalam rangka mencukupi kekurangan kebutuhan gizi dari konsumsi makan harian yang berakibat pada timbulnya masalah kesehatan dan gizi pada kelompok rawan gizi. PMT Pemulihan bagi anak usia 6-59 bulan dimaksudkan sebagai tambahan, bukan sebagai pengganti makanan utama sehari-hari.

Hasil penelitian ini sejalan dengan penelitian yang dilakukan oleh Zahra (2018), tentang perbedaan berat badan sebelum dan sesudah pemberian makanan tambahan pemulihan (PMT-P) bagi balita gizi kurang di Wilayah Kerja Puskesmas Pekalongan, Lampung Timur, diperoleh bahwa hasil analisis univariat diperoleh rerata berat badan sebelum dan sesudah Pemberian Makanan Tambahan Pemulihan (PMT-P) yaitu sebesar 8,67 $\mathrm{kg}$ dan $9,36 \mathrm{~kg}$. Analisis bivariat diperoleh adanya perbedaan berat badan sebelum dan sesudah Pemberian Makanan Tambahan Pemulihan ( $p$-value $=0,000)$.

Menurut peneliti adanya pengaruh pemberian makanan tambahan pemulihan (PMT-P) terhadap status gizi kurang pada balita disebabkan karena program PMT-P merupakan program yang dilaksanakan untuk memberikan tambahan asupan zat gizi kepada balita yang mengalami gizi kurang dimana membutuhkan asupan zat gizi yang lebih banyak dibandingkan dengan balita yang memiliki status gizi normal. Program PMT-P diberikan kepada sasaran. Selama pelaksanaan program, balita akan mendapatkan tambahan nutrisi dari makanan yang diberikan oleh petugas kesehatan selain dari pada makanan pokok yang biasa dikonsumsi sehari-hari. Selama pelaksanaan program, orang tua balita juga diberikan nasihat serta pendidikan kesehatan tentang bagaimana cara memenuhi kebutuhan nutrisi pada balita. Dengan pemberian makanan tambahan berarti akan meningkatkan asupan energi balita dan secara langsung akan berpengaruh terhadap status gizi balita, ditambah pendidikan kesehatan kepada orang tua yang bertujuan untuk meningkatkan pengetahuan tentang nutrisi pada balita dimana akan mengubah perilaku orang tua dalam pengolahan dan konsumsi makanan pokok yang memiliki nilai gizi yang cukup, sehingga akan memperbaiki status gizi balita yang bersangkutan. Untuk itu, tenaga kesehatan diharapkan dapat memaksimalkan program ini dengan lebih membedayakan kader dalam memaksimalkan cakupan pemberian PMT-P kepada balita yang membutuhkan.

\section{KESIMPULAN}

1. Rerata nilai z-skore sebelum dilakukan program pemberian makanan tambahan pemulihan (PMT-P) yaitu $-2,391 \pm 0,214$ (status gizi kurang).

2. Rerata nilai z-skore setelah dilakukan program pemberian makanan tambahan pemulihan (PMT-P) yaitu $-1,431 \pm 0,476$ (status gizi normal).

3. Terdapat pengaruh pemberian makanan tambahan pemulihan (PMT-P) terhadap status gizi kurang pada balita di wilayah kerja Puskesmas Segala Mider Bandar Lampung Tahun 2020 (pvalue $=0,000$ ), dengan rata-rata peningkatan z-skore sebelum dan sesudah dilaksanakan program PMT-P sebesar 0,959. 


\section{SARAN}

a. Bagi

Tempat Penelitian (Puskesmas Segala Mider Bandar Lampung)

1. Diharapkan bagi tenaga kesehatan di Puskesmas Segala Mider Bandar Lampung, dapat lebih rutin lagi dalam memberikan pendidikan kesehatan kepada masyarakat yang memiliki balita khususnya tentang asupan gizi balita serta memberikan leaflet tentang pemenuhan gizi balita, sehingga masyarakat dapat memiliki pengetahuan baru dan menerapkannya dalam memberi asupan makanan pada balitanya sehingga dapat mengurangi kejadian gizi kurang pada balita.

2. Diharapkan puskesmas manajemen beserta kader petugas kesehatan beserta kader dalam rangka meningkatkan keberhasilan untuk pelaksanaan PMT-P selanjutnya.

\section{b. Bagi Peneliti Selanjutnya}

Diharapkan kepada peneliti selanjutnya untuk dapat meningkatkan hasil penelitiannya mungkin dengan jumlah sampel yang lebih besar ataupun dalam ruang lingkup yang lebih luas serta meneliti variabel yang belum diteliti.

\section{c. Bagi Institusi Pendidikan}

Perlu adanya penembahan literature dan buku-buku refrensi terbaru berhubungan dengan pemberian makanan tambahan pemulihan (PMT-P) dan gizi kurang pada balita.

\section{DAFTAR PUSTAKA}

Darwis, R. E. (2017). Analisis Determinan Yang Berhubungan Dengan Kejadian Gizi Kurang Pada Balita Usia 12-59 Bulan Di Wilayah Kerja Puskesmas Benu-Benua Kota Kendari. Jimkesmas, Vol.2, No.6.

Fitrianti, F. (2012). Pengaruh Pemberian Makanan Tambahan Pemulihan (PMT-P) Terhadap Status Gizi Balita Gizi Buruk di Dinas Kesehatan Kota Semarang.Journal of Nutrition College, Vol. 1, No. 1, Juni 2012. p.373-381.

Kementerian Kesehatan Republik Indonesia. (2017). Buku Saku Penilaian Status Gizi. Jakarta : KementerianKesehatan RI.

Kementerian Kesehatan Republik Indonesia. (2017). Petunjuk Teknis Pemberian Makanan Tambahan (Balita-Ibu HamilAnak Sekolah). Jakarta : KementerianKesehatan RI.

Kementerian Kesehatan Republik Indonesia. (2018). Profil Kesehatan Republik Indonesia Tahun 2018. Jakarta.

Kementerian Kesehatan Republik Indonesia. (2018). Riset Kesehatan Dasar Tahun 2018. Jakarta.

Marimbi, H. (2012). Tumbuh Kembang, Status Gizi dan Imunisasi Dasar Pada Balita. Jakarta: Nuha Medika.

Rini, I. (2017). Pengaruh Pemberian Makanan Tambahan Pemulihan (PMT-P) Terhadap Perubahan Status Gizi Balita Gizi Buruk di Rumah Gizi Kota Semarang tahun 2017. Jurnal Kesehatan Masyarakat (eJournal) Volume 5, Nomor 4, Oktober 2017.

Sulistyoningsih, H. (2011). Gizi untuk Kesehatan Ibu dan Anak. Yogyakarta: Graha Ilmu. 
Supariasa, dkk. (2017). Penilaian Status Gizi. Jakarta: EGC.

Tanto, Crist, dkk. (2014). Kapita Selekta Kedokteran. Jakarta Media Aesculapius.

Zahra A. P. (2018). Perbedaan Berat Badan Sebelum Dan Sesudah Pemberian Makanan Tambahan Pemulihan (PMT-P) Bagi Balita Gizi Kurang di Wilayah Kerja Puskesmas Pekalongan, Lampung Timur.Jurnal Universitas Lampung, vol. 1, no. 1. Januari 2018. 